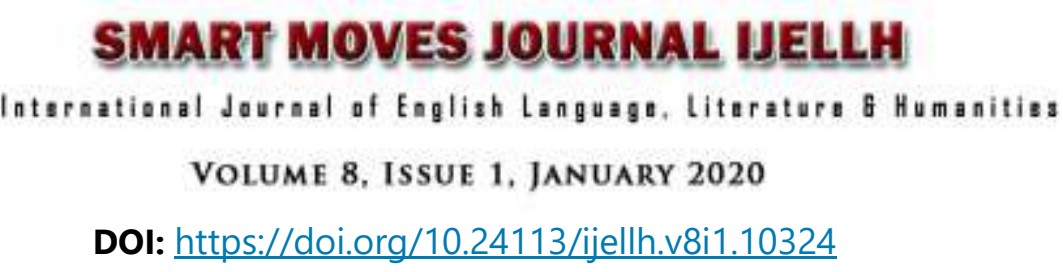

\title{
Changing Contours of Nature: An Ecocritical Exploration of the Select Poems of Nissim Ezekiel and Stephen Spender
}

\author{
Dr.V. Bhuvaneswari \\ Associate Professor \\ Department of English \\ SSL, VIT, \\ Vellore, Tamil Nadu, India \\ vbhuvaneswari@vit.ac.in
}

Abstract

In an age where digital, virtual and augmented reality discourses are on an upsurge, the need to call for an environmental discourse is of paramount importance. Environmental literature or Eco literature stresses on the establishment of a strong bond between human and his or her immediate environment. A scrutiny of the works by eminent poets both East and West discloses the changing contours of nature. The changing landscapes, the extinction of flora and fauna, the diminishing relationship between humans and nonhumans are vividly and exquisitely rendered better by exuberant poets than any other creators. As a theoretical approach, ecocriticism grew out of the traditional approach in literature that addresses how humans relate to the nonhuman world or the environment in literature. In order to highlight the ecological transformation that has taken place from the past to the present, from the rural to the urban and from the local to global the present study has taken for analysis the select poems of the distinguished Indian poet Nissim Ezekiel and the renowned British poet Stephen Spender. 
Further, the select poems of Nissim Ezekiel and Stephen Spender are examined from an ecocritical lens.

Keywords: Ecocriticism, humans, nonhumans, Nissim Ezekiel, Stephen Spender

Introduction

We are living in a fast moving world and as William Henry Davies says "What is this life full of care, We have no time to stand and stare". In this technocratic world, we are racing with machines where nature is often or completely ignored. The time has come to realize the potential threat to our very survival on this earth. Global warming and climate change remind humans of their greatest mistake of what they have done to the environment. In an age where digital, virtual and augmented reality discourses are on an upsurge the need to call for an environmental discourse is of paramount importance.

Environmental literature or Eco literature stresses on the establishment of a strong bond between human and his or her immediate environment. As an emerging theory Ecocriticism takes on an earth centric approach towards literary theory. The term was coined and used by William Rueckert in his essay entitled "Literature and Ecology: An Experiment in Ecocriticism" where he defines ecocriticism as "the application of ecology and ecological concepts to the study of literature" (p.107). The establishment of a new Association for the Study of Literature and Environment (ASLE) in 1992 under the august leadership of Scott Slovic and Cheryll Glotfelty paved way for its development. The objective of this association is to create a nexus between human beings and the natural world and to encourage interdisciplinary scholarly approach to literature and environment. Since its advent, eminent scholars like Lawrence Buell, Simon C. Estok, Urusula K. Heise, and Allison B. Wallace have contributed a lot to the development of ecocriticism. Buell defines ecocriticism as "the study 
of relationship between literature and the environment conducted in a spirit of environment to environmentalist praxis" (p. 430). In addition Christopher Cokinos in his essay describes ecocriticism as a "critical and pedagogical broadening of literary studies to include texts that deal with the non-human and our relationship to it" (p.3).

The changing landscapes, the extinction of flora and fauna, the diminishing relationship between humans and nonhumans are vividly and exquisitely rendered better by the exuberant poets than any other creators. A scrutiny of the works by eminent poets both East and West discloses the changing contours of nature. In order to highlight the ecological transformation that has taken place from the past to the present, from the rural to the urban and from the local to global the present study has taken for analysis the select poems of the distinguished Indian poet Nissim Ezekiel and the renowned British poet Stephen Spender. Further, the select poems of Nissim Ezekiel and Stephen Spender are examined from an ecocritical lens.

Stephen Harold Spender (1909-1995), was an English poet, translator, literary critic and an editor. Spender is quite often associated with great poets like W.H.Auden, Cecil Day Lewis and Christopher Isherwood. Like his contemporaries, Spender believed that the modern industrial revolution has made man estrange from nature. His poems are engrossed with the conflicting images of modern and tradition topped with naturalness of expression. It is befitting to compare him with the father of contemporary Indian English poetry, Nissim Ezekiel. Ezekiel, a recipient of Sahitya Academy Award, is known for "addressing the actualities of experience honestly in an honest and appropriate language." (Dulai, p.123). Both these poets are vivid in their expression and intrepid in expressing the ground reality of the world around them. Hence, an attempt has been made to compare their select poems from an ecocritical 
perspective. The poems that are selected for the study are The Landscape near Aerodrome, The Pylons and An Elementary School Classroom in a Slum by Stephen Spender and Urban, Hill and The Night of the Scorpion by Nissim Ezekiel.

Spender in his poem The Landscape near Aerodrome vividly describes the changing landscape near an Aerodrome thus:

Behind the aerodrome, where boys play all day

Hacking dead grass: whose cries, like wild birds

Settle upon the nearest roofs

But soon are hid under the loud city.

(The Landscape near Aerodrome L. 23-26)

There were pristine fields covered with green grass once and boys in their childhood frenzy played all day and night. All these activities can be seen in almost all the villages before the advent of technology but after the building up of an aerodrome the green grass has become "dead grass". Dolezal in his article states that "industry has scared the landscape" (p.3). Moreover the city with its hustle and bustle has become loud and the cries of the wild birds are almost unheard. From a tranquil landscape the beautiful place has become a "landscape of hysteria" (Landscape, L.28).

Similarly, in the poem The Pylons Spender picturizes the exquisiteness of the hilly region thus:

The secret of these hills was stone, and cottages

Of that stone made

And crumbling roads

That turned on sudden hidden villages (The Pylons L.1-3)

Spender emphasises that in those days people built cottages out of the stones from the hill. Those cottages has stood the test of time bravely facing the natural calamities. On the contrary modern man has built concrete roads and houses that wither with the wind and flood. Spender describes this transformation from naturally formed stones to the man-made concrete in his line: "Now over these small hills, they have built the concrete" (The Pylons L.5). Spender 
further expands the description from the hill to the valley. The valley that glittered by the beautiful radiance of the sunset has now become dry like the parched brook.

The valley with its gilt and evening look

And the green chestnut

Of customary root,

Are mocked dry like the parched bed of brook. (The Pylons L.9-12).

Similar to Spender's poem Nissim Ezekiel's poem Urban exposes the changing landscape thus:

The hills are always far away.

He knows the broken roads, and moves

In circles tracked within his head

Before he wakes and has his say,

The river which he claims he loves

Is dry, and all the winds lie dead. (Urban, L.1-6)

Ezekiel questions his readers through his lines: "What is survival? What is existence?" (Hill, L. 31-32) and provides the answer "I say: you've got to love that hill" (Hill, L.41-42).

Just imagine the world we live now. True to the words of Frost "good fences makes good neighbours" we are confined to the four walls not bothered about our neighbours or the outside world. On the contrary, we need to live a life of interdependence, just as Ezekiel explains the significance of coexistence in his poem The Night of the Scorpion. When the mother is bit by the scorpion the villagers rushed to her aid. Can we see such a situation now? Ezekiel describes the scene thus: "The peasants came like swarms of flies/ and buzzed the name of God a hundred times..." (The Night of the Scorpion, L. 8-9). With the advancement of science and technology modern man has ignored his neighbours as well as his immediate environment. 


\section{Conclusion:}

Spender as well as Ezekiel through their enchanting lines reminds their readers that this is the place, the river, the hill, the plains, the valley, and the village where we all belong. As a good native we should stay in the place and protect and preserve its serenity for the progeny. It is very evident from their poems that though both these poets belong to the East and West, different in regions yet share the same viewpoint, that an interconnected way of living with nature can provide a panacea for all ecological problems. Failure to address the ecological problems will lead to man's catastrophe. Hence, the poems of Spender and Ezekiel assume greater value and significance today in stressing the importance of maintaining the ecological balance. 


\section{Works Cited}

Buell, Lawrence. The Environmental Imagination: Thoreau, Nature Writing, and the Formation of American Culture. Harvard University Press, England. (1995) p.430

Cokinos, C. What is ecocriticism, Defining Ecocritical Theory and Practice Sixteen Position Papers from the 1994 Western Literature Association Meeting ASLE, (1994). pp.1-18.

Dolezal A. Joshua ."Literary Activism, Social Justice, and the Future of Bioregionalism", Ethics and the Environment, Vol. 13, No.1 (Spring) (2008),pp.1-22.

Dulai S.Surjit. "Nissim Ezekeil: The Father of Contemporary Indian English Poetry" Journal of South Asian Literature, Vol.35, No.1\&2, (2000).p.123

Rueckert, William..Literature and Ecology: An Experiment in Ecocriticism, In: C.Glotfety and H. Fromm (eds), Ecocriticism Reader: Landmark in Literary Ecology, U of Georgia Press, London. (1996). pp.105-123.

Spender, Stephen . https://www.poemhunter.com/stephen-spender/poems/ Web. 9 Dec. 2019

Ezekiel, Nissim.https://www.poemhunter.com/nissim-ezekiel/poems/ Web. 9 Dec. 2019 